\title{
Effects of Paclobutrazol on Dry Matter Accumulation and Grain Filling of Castor Bean
}

\author{
Chengyu Song ${ }^{1,2}$, Guanglong Zhu ${ }^{1,2}$, Xiurong Jiao ${ }^{1,2}$, Guisheng Zhou ${ }^{1,2, *}$ \\ ${ }^{1}$ Joint International Research Laboratory of Agriculture and Agri-Product Safety of Ministry of Education of China, Yangzhou University, \\ Yangzhou, China \\ ${ }^{2}$ Jiangsu Provincial Key Laboratory of Crop Genetics and Physiology, Yangzhou University, Yangzhou, China
}

Email address:

gszhou@yzu.edu.cn (Guisheng Zhou)

${ }^{*}$ Corresponding author.

\section{To cite this article:}

Chengyu Song, Guanglong Zhu, Xiurong Jiao, Guisheng Zhou. Effects of Paclobutrazol on Dry Matter Accumulation and Grain Filling of Castor Bean. American Journal of Biological and Environmental Statistics. Vol. 4, No. 3, 2018, pp. 83-90.

doi: $10.11648 /$ j.ajbes.20180403.11

Received: August 20, 2018; Accepted: September 14, 2018; Published: October 17, 2018

\begin{abstract}
Castor bean (Ricinus communis L.) as a bioenergy crop, received more and more attention in recent years. However, the yield of castor bean seeds is affected by adverse environmental conditions. The objective of this study was to assess the effects of exogenous application of Paclobutrazol (PBZ) on castor bean growth, yield and physiology as well as on its response to environmental stress during grain filling. In the present field study, three PBZ concentrations [0 g ha- 1 (control), $75 \mathrm{~g}$.ha-1 and $150 \mathrm{~g}$.ha-1] were applied twice, once at grain filling of main panicle and once at grain filling of branched panicle. The growth and physiological responses of castor bean were measured four times throughout flowering and seed formation stages [1-early initiation stage of main inflorescence (E), 2- anthesis of main inflorescence (A), 3-maturity of main panicle (M) and 4-maturity of branched panicle (B)]. Plant growth was not affected by the application of PBZ, but leaves remained later on the plant when $75 \mathrm{~g} \cdot$ ha-1 of PBZ was applied. With the application of PBZ, the concentration of starch was higher in panicles than in leaves and stems. Also, PBZ application increased the number of seeds per plant without affecting seed size and weight. These results suggest that exogenous application of PBZ can enhance sink strength of panicles and improve seed yield and that application of PBZ at flower initiation can alter photosynthetic partitioning in favor to seed production. On the other hand, PBZ had no effect on antioxidant enzyme activity in the seeds in response to stress.
\end{abstract}

Keywords: Castor Bean, Paclobutrazol, Grain Filling, Dry Matter Accumulation

\section{Introduction}

Castor bean (Ricinus communis L.) is a fast growing shrub that could reach a height up to $12 \mathrm{~m}$. It is an important oilseed crop which produces oil containing over $80 \%$ of ricinoleic acid [1] which has a high value and versatile applications in the chemical industry [2]. Currently, about $1 \mathrm{Mt}$ of castor bean is harvested annually for oil production, with India, China and Brazil being the major producers [2]. In addition to its primarily use as laxative to counter constipation [3], castor bean oil can be used as base oil in the formulations for lubricants, feedstock for fuels and oleo-chemicals, as well as reactive component for paints, coatings and inks, polymers and foams [4-5].
Bioenergy production combined with phytoremediation has been suggested as avenues to privilege to gradually reduce the use of fossil fuels and soil contamination worldwide [6]. In recent years, castor bean has become increasingly attractive as a potential bioenergy crop for biofuel production, because of its high seed-oil production [7-8]. This species has also shown a good potential in phytoremediation by hyper accumulation of soil contaminants such as metal and DDT [9-10]. As such castor bean could be considered as a good dual-bioenergy crop for bioenergy/bioproducts production and phytoremediation [11]. The current production of castor bean is however not 
sufficient to meet the worldwide demand and both yield and cropping area have to be increased.

In China, castor bean plantations on coastal saline marginal land have emerged to satisfy the need for castor bean oil while at the same time avoiding competition for food production [2-3]. The yield of castor bean seeds is however negatively affected by the adverse saline and environmental conditions found in coastal areas. Castor bean is a fast growing shrub which growth is characterized by excessive vegetative growth. Since the vegetative growth is made at the expense of seed yield, a possible solution to reduce the negative impact of saline conditions on seed yield would be to promote reproductive development in place of excess vegetative growth [12].

In that perspective, the external application of plant growth regulators has been suggested to control the indeterminate growth of castor bean and improve panicle formation and grain filling [13]. Plant growth regulators can increase agricultural production through multiple effects on plant function such as induction of flowering, maturation and aging [14].

Pacobutrazol (PBZ) is a plant growth regulator acting as an inhibitor of gibberellin biosynthesis [15]. Which has been shown to arrest vegetative growth and increase seed yield in jatropha [16], and canola [17], and to favour tuber yield in potato [18]. PBZ has also been reported to increase abiotic stress tolerance in maize, likely through an increase in antioxidant enzymes concentration or activity in treated plants [19-21].

The objective of this study was to assess the effect of PBZ application on castor bean growth and seed yield. The hypothesis was that PBZ application could decrease castor bean vegetative growth, while increasing panicle formation and seed yield. To reach this goal, three PBZ concentrations were applied at two different times during castor bean development, in an effort to increase the knowledge on optimal PBZ management with this species. In addition, to better understand the role of PBZ application on castor bean response to environmental stress, the concentration of antioxidant enzymes involved in plant stress tolerance [22-24] were measured in seeds during grain filling.

\section{Materials and Methods}

A field study was conducted in 2016 and 2017 at the Experimental Farm of Yangzhou University (32 $30^{\prime} \mathrm{N}$, $\left.119^{\circ} 25^{\prime} \mathrm{E}\right)$, Jiangsu Province, China. Weather conditions at field site are described in Table 1.

Uniform-sized castor bean seeds of Zibi 9, kindly provided by Zibo Academy of Agricultural Science (Shandong Province, China), were selected and immersed in warm water $\left(75^{\circ} \mathrm{C}\right)$ for $30 \mathrm{~min}$ to maximize germination potential. Plots were seeded by direct seeding. The study consisted in 6 plots (3 PBZ concentration $\times 2$ application times) repeated 3 times for a total of 18 plots. Each plot was $3.5 \mathrm{~m}$ wide by $8 \mathrm{~m}$ long for a total area of $28 \mathrm{~m}^{2}$. The row spacing was of $1 \mathrm{~m}$ and the distance between plants of $0.67 \mathrm{~m}$ for a total of 48 plants per plot. Urea $\left(300 \mathrm{~kg} \cdot \mathrm{ha}^{-1}\right)$ was used as $\mathrm{N}$ fertilizer, calcium superphosphate $\left(180 \mathrm{~kg} \cdot \mathrm{ha}^{-1}\right)$ as phosphate fertilizer, and potash $\left(270 \mathrm{~kg} \cdot \mathrm{ha}^{-1}\right)$ as phosphate fertilizer. Fertilizers were applied twice, half at flowering and half at seed formation.

The study was a randomized complete block design with two factors. The first factor was the application time of PBZ, either at early grain filling stage of main panicle or at early grain filling stage of branched panicle. The second factor was the concentration of PBZ applied with three levels $\left[0 \mathrm{~g} \cdot \mathrm{ha}^{-1}\right.$ (control), $75 \mathrm{~g} \cdot \mathrm{ha}^{-1}$ and $\left.150 \mathrm{~g} \cdot \mathrm{ha}^{-1}\right]$.

Table 1. Field and weather conditions (total rain, percentage of salinity in the field; Max temp, the highest temperature during the growth period for 2016 and 2017). (Rainfall data are from the annual environmental quality bulletin of the Yangzhou Environmental Protection Bureau [25-26]. Field salinity was measured with a conductivity meter before sowing. The max temperature are from the weather website of major Chinese cities including Yangzhou [27-28].).

\begin{tabular}{lll}
\hline & $\mathbf{2 0 1 6}$ & $\mathbf{2 0 1 7}$ \\
\hline Total rain(mm) & 1755 & 848.8 \\
Field salinity & $0,30 \%$ & $0,30 \%$ \\
Max temp & $39^{\circ} \mathrm{C}$ & $40^{\circ} \mathrm{C}$ \\
\hline
\end{tabular}

\subsection{Plant Measurements}

\subsubsection{Morphological and Physiological Parameters}

At four growth stages during the experiments [1-early initiation stage of main inflorescence (E), 2- anthesis of main inflorescence (A), 3-maturity of main panicle (M), 4-maturity of branched panicle (B)], 10 plants for each replicate of each treatment were randomly chosen for the measurement of plant height, branch number, capsule number, and the width and length of panicles. Each data for plant height $(\mathrm{cm})$ and branch number was the mean of 10 plants. Length and width of panicle $(\mathrm{cm})$ was the mean of all panicles on one plant (chosen randomly in the experimental unit).

Also on these four dates, two plants for each replicate of each treatment were randomly harvested. Each plant was divided into panicle, stem and leaf. The leaf area was determined using a leaf area meter (Model Li-3000A, LICOR, Inc., Lincoln, NE). Then all the plant samples were oven-dried at $105^{\circ} \mathrm{C}$ for 15 minutes and then dried at $80^{\circ} \mathrm{C}$ until constant weight was reached for the determination of biomass yield, and soluble sugar and starch concentration.

\subsubsection{Grain Filling}

Ten capsules for each replicate of each treatment were randomly chosen for the measurement of capsule weight at 3 , $6,9,15,21,27,33,39$ and 45 days after flowering. Capsules were stored in a low-temperature freezer $\left(-80^{\circ} \mathrm{C}\right)$ until the determination of POD and CAT.

\subsubsection{Seed Characterization}

Seed size $(\mathrm{cm})$ was determined by measuring their length and width. Length $(\mathrm{cm})$ and width of seeds $(\mathrm{cm})$ were the average of the seeds of ten plants at stage B. Average seed weight was obtained from a random batch of 100 seeds. Number of seeds per plant and hundred-seeds weight (g) was the average for ten plants. 


\subsubsection{Content of Soluble Sugar and Starch:}

The content of soluble sugar was measured according to Laurentin, et al. [29]. Briefly, $100 \mathrm{mg}$ of sample were homogenised with $10 \mathrm{ml}$ of $80 \%$ ethanol solution using a mortar and a pestle. After heating the homogenate in a water bath at $80^{\circ} \mathrm{C}$ for $30 \mathrm{~min}$, insoluble residues were removed by centrifugation at $2000 \mathrm{r}$ for $15 \mathrm{~min}$. The precipitate was reextracted twice with $10 \mathrm{ml}$ of $80 \%$ ethanol at $80^{\circ} \mathrm{C}$ followed by a centrifugation. The combined supernatant was used for soluble sugar determinations and pellets were used for starch determinations by adding $0.2 \%$ anthrone into supernatant and potassium perchlorate to pellets. Glucose concentration in samples was measured using a spectrophotometer (Model 721, Shanghai Mapada Instruments Co. Ltd, Shanghai), set at $620 \mathrm{~nm}$. The content of soluble sugars and starch was calculated based on a glucose standard curve.

\subsection{Enzyme Analyses}

\subsubsection{POD Activity Assay}

The activity of peroxidase (POD) was assayed according to the method of Wang and Luh [30] with minor modification. Castor bean seeds POD was extracted by homogenising the seeds $(0.5 \mathrm{~g})$ from 10 capsules with $5 \mathrm{ml}$ of $0.05 \mathrm{M}$ phosphate buffer ( $\mathrm{pH} 7.0)$. The homogenate was centrifuged for $15 \mathrm{~min}$ at $15000 \mathrm{r}$ at $4{ }^{\circ} \mathrm{C}$ and then the supernatant containing the crude enzyme extract was collected and added to the reaction mixture $(4 \mathrm{ml})$, containing $0.1 \mathrm{ml}$ enzyme extract, $1 \mathrm{ml} 0.05$ $\mathrm{M}$ phosphate buffer ( $\mathrm{PH} 7.0$ ), $1.95 \mathrm{ml}$ of $3 \% \mathrm{H}_{2} \mathrm{O}_{2}$ and 0.95 $\mathrm{ml}$ of $0.2 \%$ guaiacol. The increase in absorbance at $470 \mathrm{~nm}$ due to guaiacol oxidation was recorded during $2 \mathrm{~min}$. One unit of enzyme activity was defined as the amount of enzyme which causing a change of 0.1 in absorbance per minute.

\subsubsection{CAT Activity Assay}

The activity of catalase (CAT) was assayed according to the method of Cohen, et al. [31] with minor modifications. The same extract of castor bean seeds was used for POD and CAT activity determination. The supernatant containing the crude enzyme extract was added to the reaction mixture $(3 \mathrm{ml})$, containing $0.1 \mathrm{ml}$ enzyme extract, $1 \mathrm{ml}$ of $3 \% \mathrm{H}_{2} \mathrm{O}_{2}$ and $1.9 \mathrm{ml}$ $\mathrm{H}_{2} \mathrm{O}$. The decrease in absorbance at $240 \mathrm{~nm}$ due to hydrogen peroxide disappearance was recorded for $2 \mathrm{~min}$. One unit of enzyme activity was defined as the amount of enzyme which causing a change of 0.1 in absorbance per minute.

\subsubsection{Statistical Analyses}

The experiment was performed twice, in 2016 and 2017 in the same field. For field and seed data, a three-way analysis of variance with complete randomized block design was used to study the effects of PBZ concentration and time of application. Models were implemented using MIXED procedure of the SAS software. Residual analysis was performed to verify data normality and homogeneity. When homogeneity assumption was violated, the REPEATED statement was used to model the heterogeneity in the data.

For enzyme activities and starch, a four way analysis of variance was used to study the effects of PBZ concentration and time of application. There were no repetitions for this experiment; the fourth order interaction was used as the error to obtain p-values. Models were implemented using MIXED procedure of the SAS software. Multiple comparisons were made using Tukey adjustment. Residual analysis was performed to verify the normality and homogeneity assumptions. «POD variable» was transformed with the logarithm to satisfy the normality assumption.

A four way analysis of variance with year as random factor was used to study the effects of PBZ concentration and time of application on sugar concentration. Models were implemented using MIXED procedure of the SAS software. Multiple comparisons were made using Tukey adjustment. Residual analysis was performed to verify the normality and homogeneity assumptions. All variables were transformed with the logarithm to satisfy the normality assumption [32].

\section{Results}

\subsection{Morphological Parameters}

A significant effect of sampling time on plant height with higher height at the last sampling stage (B) than at the three previous stages (Table 2). PBZ did not have a significant effect on plant height but there was a tendency for the plants to be shorter with PBZ application (75 and $\left.150 \mathrm{~g} \cdot \mathrm{ha}^{-1}\right)$ at $\mathrm{E}$, $\mathrm{A}$ and $\mathrm{M}$ as compared to control plant $\left(0 \mathrm{~g} \cdot \mathrm{ha}^{-1}\right)$ (Figure 1$)$.

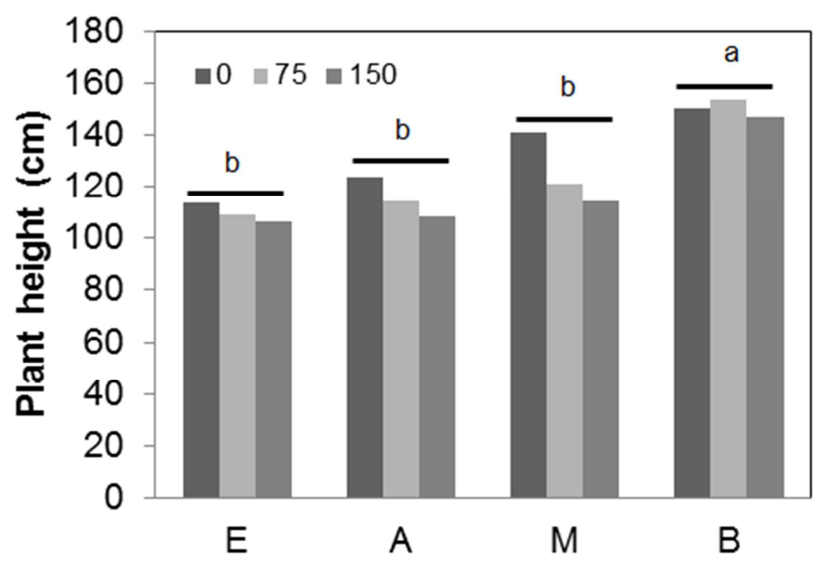

Figure 1. Plant height under three PBZ application rates $(0,75$, and 150 $\left.\mathrm{g} \cdot \mathrm{ha}^{-1}\right)$ measured at different successive sampling time corresponding to the following development stages ( $E=$ Early initiation stage of main inflorescence, $A=$ Anthesis of main inflorescence, $M=$ Maturity of main panicle, and $B=$ Maturity of branched panicle). Different letters indicate significant differences at $P<0.05$ between sampling dates. 
Table 2. P value of the analysis of variance for plant height, leaf area, length of panicle, width of panicle, branch number and capsule number of castor bean grown under different PBZ concentration $\left(0,75\right.$ and $\left.150 \mathrm{~g} \cdot \mathrm{ha}^{-1}\right)$, applied either at early grain filling of main panicle or early grain filling of branched panicle. Sampling time corresponding to the following growth stage: E= Early initiation stage of main inflorescence, A=Anthesis of main inflorescence, M= Maturity of main panicle, and $B=$ Maturity of branched panicle. NS= not significant.

\begin{tabular}{|c|c|c|c|c|c|c|}
\hline & $\begin{array}{l}\text { Plant height } \\
\text { (cm per plant) }\end{array}$ & $\begin{array}{l}\text { Leaf area } \\
\left(\mathrm{cm}^{2} \text { per plant }\right)\end{array}$ & $\begin{array}{l}\text { Length of panicle } \\
\text { (cm per plant) }\end{array}$ & $\begin{array}{l}\text { Width of panicle } \\
\text { (cm per plant) }\end{array}$ & $\begin{array}{l}\text { Branch number } \\
\text { (per plant) }\end{array}$ & $\begin{array}{l}\text { Capsule number } \\
\text { (per plant) }\end{array}$ \\
\hline PBZ (P) & NS & $\mathrm{NS}$ & NS & $\mathrm{NS}$ & NS & NS \\
\hline Application time (A) & NS & NS & NS & NS & NS & NS \\
\hline Sampling time (S) & 0.0007 & NS & 0.018 & 0.0068 & $<.0001$ & $<.0001$ \\
\hline $\mathrm{P} \times \mathrm{A}$ & NS & NS & 0,0415 & NS & NS & NS \\
\hline $\mathrm{P} \times \mathrm{S}$ & NS & 0.0341 & NS & NS & NS & NS \\
\hline $\mathrm{P} \times \mathrm{A} \times \mathrm{S}$ & NS & NS & NS & NS & NS & NS \\
\hline
\end{tabular}

Branch number, length and width of panicle increased during plant development and reached a maximum at stage $\mathrm{M}$ and then decreased between $\mathrm{M}$ and $\mathrm{B}$ (Table 3). When sampled at the mature of main panicle $(\mathrm{M})$, the number of branch reached 1.94 per plant and was $185 \%, 83 \%$ and $102 \%$ higher than at the other three sampling times (E, A and B), respectively. The average of length and width of panicle were significantly larger at maturity of main panicle (M) as compared to early initiation stage of main inflorescence (E) (Table 3).

Table 3. Capsule number, branch number, length of panicle and width of panicle at successive sampling times.

\begin{tabular}{lllll}
\hline Sampling time & Capsule number (per plant) & Branch number (per plant) & Length of panicle (cm) & Width of panicle (cm) \\
\hline $\mathrm{E}$ & none & $0.68 \mathrm{~B}$ & $21.05 \mathrm{~B}$ & $7.64 \mathrm{~B}$ \\
$\mathrm{~A}$ & $60.57 \mathrm{BC}$ & $1.06 \mathrm{~B}$ & $24.22 \mathrm{AB}$ & $8.91 \mathrm{AB}$ \\
$\mathrm{M}$ & $75.43 \mathrm{AB}$ & $1.94 \mathrm{~A}$ & $26.33 \mathrm{~A}$ & $10.84 \mathrm{~A}$ \\
$\mathrm{~B}$ & $91.99 \mathrm{~A}$ & $0.96 \mathrm{~B}$ & $24.10 \mathrm{AB}$ & $9.35 \mathrm{AB}$ \\
\hline
\end{tabular}

$\mathrm{E}=$ Early initiation stage of main inflorescence, $\mathrm{A}=$ Anthesis of main inflorescence, $\mathrm{M}=$ Maturity of main panicle, and $\mathrm{B}=\mathrm{Maturity}$ of branched panicle. Within column, means followed by the same letter are not significantly different at $\mathrm{P}=0.05$

There was a significant interaction between PBZ application rates and sampling time (Table 2). This was shown by an increase in leaf area between stage $\mathrm{A}$ and $\mathrm{M}$ and then a sharp decrease between stage $\mathrm{M}$ and $\mathrm{B}$ in response to control $\left(0 \mathrm{~g} \cdot \mathrm{ha}^{-1}\right)$ and $150 \mathrm{~g} \cdot \mathrm{ha}^{-1}$ of PBZ. For the $75 \mathrm{~g} \cdot \mathrm{ha}^{-1}$ application rate, leaf area decreased between stage $\mathrm{E}$ and $\mathrm{A}$, and then remained stable until the end of the experiment (stage B) (Figure 2).

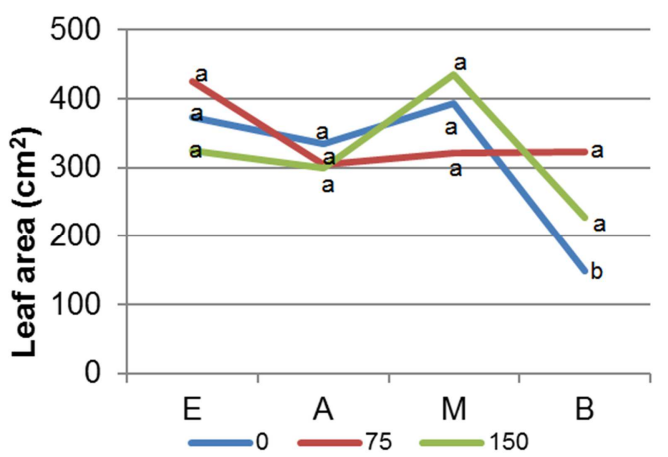

Figure 2. Leaf area of Castor bean in response to three PBZ application rates $\left(0,75\right.$, and $\left.150 \mathrm{~g} \cdot \mathrm{ha}^{-1}\right)$ measured at four different successive sampling time corresponding to the following development stages: $E=$ Early initiation stage of main inflorescence, $A=$ Anthesis of main inflorescence, $M=$ Maturity of main panicle, and $B=$ Maturity of branched panicle. Within a development stage, different letters indicate significant differences between $P B Z$ applications at $P \leq 0.05$.

At the first sampling stage (E) dry weight of panicle was significantly lower than leaf and stem dry weight. At A and
$\mathrm{M}$, the dry weight of the three plant tissues were similar while at the last sampling time (B), dry weight of panicles and stems were similar and much larger than leaf dry weight (Figure 3).

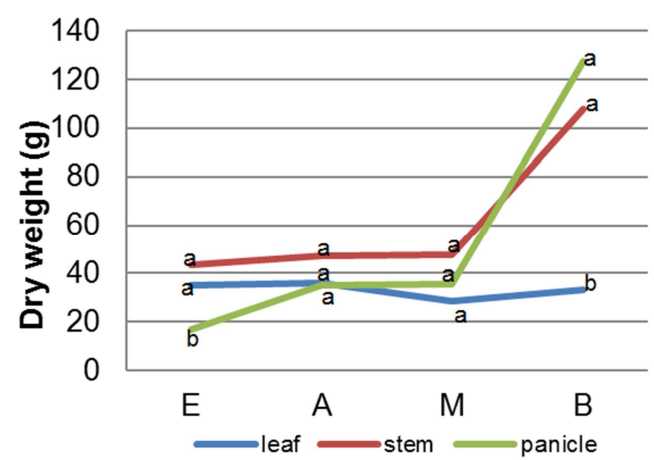

Figure 3. Dry weight of Castor bean leaves, stems and panicles measured at four different successive sampling time corresponding to the following development stages: $E=$ Early initiation stage of main inflorescence, $A=$ Anthesis of main inflorescence, $M=$ Maturity of main panicle, and $B=$ Maturity of branched panicle. Within a development stage, different letters indicate significant differences between the three tissues at $P \leq 0.05$.

PBZ application had a significant effect on the number of seeds per plant: the number of seeds per plant was significantly higher under the concentration of $150 \mathrm{~g} \cdot \mathrm{ha}^{-1}$ than in control plants $\left(0 \mathrm{~g} \cdot \mathrm{ha}^{-1}\right)$. With increasing concentrations of PBZ, the length and width of seeds and 100 seeds weight was slightly higher but the effect was not significant (Table 4). 
Table 4. Average seed length and width, number of seeds per plant and weight of 100 seeds in response to three PBZ application rate: 0,75 and $150 \mathrm{~g} \cdot \mathrm{ha}-1$. The values were averaged for the two application times ( $M$ and $B, n=4$ ).

\begin{tabular}{lllll}
\hline PBZ concentration & seed length $(\mathbf{m m})$ & seed width $(\mathbf{m m})$ & seeds per plant & $\mathbf{1 0 0}$ seeds weight $(\mathbf{g})$ \\
\hline $0 \mathrm{~g} \cdot \mathrm{ha}^{-1}$ & $13.04 \mathrm{~ns}$ & $8.18 \mathrm{~ns}$ & $306 \mathrm{~b}^{*}$ & $27.72 \mathrm{~ns}$ \\
$75 \mathrm{~g} \cdot \mathrm{ha}^{-1}$ & $13.44 \mathrm{~ns}$ & $8.55 \mathrm{~ns}$ & $432 \mathrm{ab}$ & $29.64 \mathrm{~ns}$ \\
$150 \mathrm{~g} \cdot \mathrm{ha}^{-1}$ & $13.90 \mathrm{~ns}$ & $8.68 \mathrm{~ns}$ & $551 \mathrm{a}$ & $30.29 \mathrm{~ns}$ \\
\hline
\end{tabular}

*within a column, different letters indicate significant differences at $\mathrm{p}<0.05$. ns $=$ no significant differences

\subsection{Physiological Parameters}

At the beginning of the experiment $(\mathrm{E})$, the concentration of soluble sugar was significantly lower in panicle than in leaves and stems. Between $\mathrm{E}$ and $\mathrm{A}$, there was a sharp decrease of soluble sugar in leaves and stems concomitant with an increase in panicle, resulting in a significant higher soluble sugar concentration in panicle than in the other two tissues. At the two later stages, soluble sugar concentrations were similar for all tissues (Figure 4).

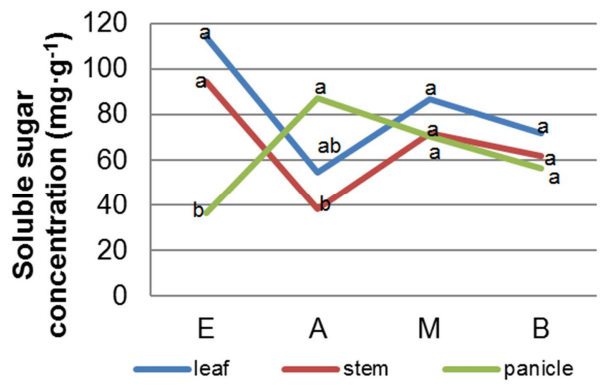

Figure 4. Concentration of soluble sugars in three different tissues leaf, stem and panicle) of Castor bean measured at four different successive sampling time corresponding to the following development stages: E= Early initiation stage of main inflorescence, $A=$ Anthesis of main inflorescence, $M=$ Maturity of main panicle, and $B=$ Maturity of branched panicle. Within a development stage, different letters indicate significant differences between the three tissues at $P<0.05$.

At stage E, Application of PBZ had a significant effect on starch accumulation in different tissues of Castor bean $(\mathrm{P}=0.02)$. There was a higher starch concentration in panicle than in leaves and stems, and a significantly higher concentration under $150 \mathrm{~g} \cdot \mathrm{ha}^{-1}$ of PBZ in panicle. For the other tissues, a similar tendency was observed (Figure 5).

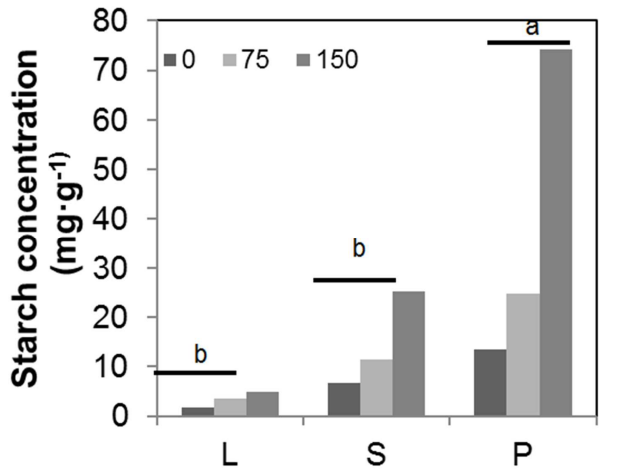

Figure 5. Starch concentration of different tissues of Castor bean ( $L=L e a f$, $S=$ Stem and $P=$ Panicle) at early initiation stage of main inflorescence (stage E) in response to three PBZ application rates $\left(0,75\right.$, and $\left.150 \mathrm{~g} \cdot \mathrm{ha}^{-1}\right)$. Different letters indicate significant differences between the three tissues at $P \leq 0.05$.

\subsection{Grain Filling}

During grain filling stage, the capsule weight increased from day 3 to day 15 when it reached its highest weight, and then decreased between day 15 and day 27. After day 27, capsule weight remained stable until the completion of grain filling. On day 15 , the capsule weight was higher than on day 3 (Figure 6).

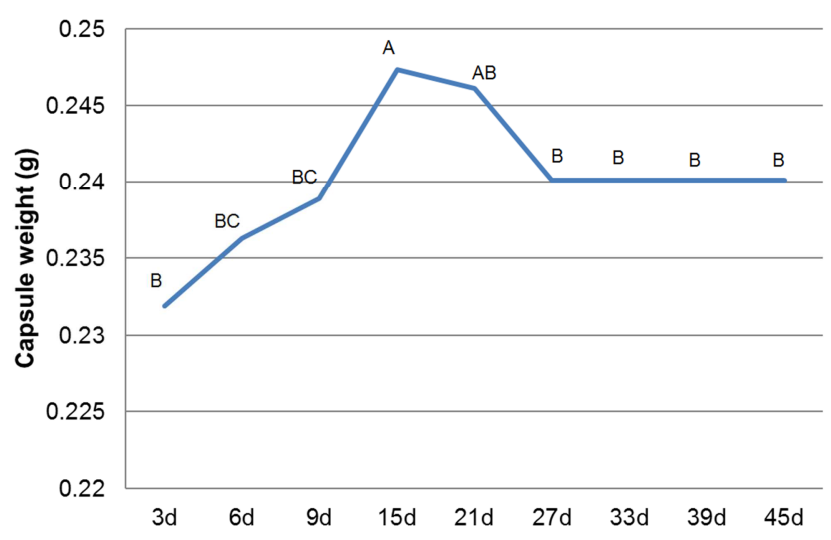

Figure 6. Capsule weight corresponding to successive grain filling days. Different letters indicate significant differences between the sampling days at $P \leq 0.05$.

Since there was no significant effect of PBZ on enzyme activity, the average activity in response to the three PBZ treatments is presented.

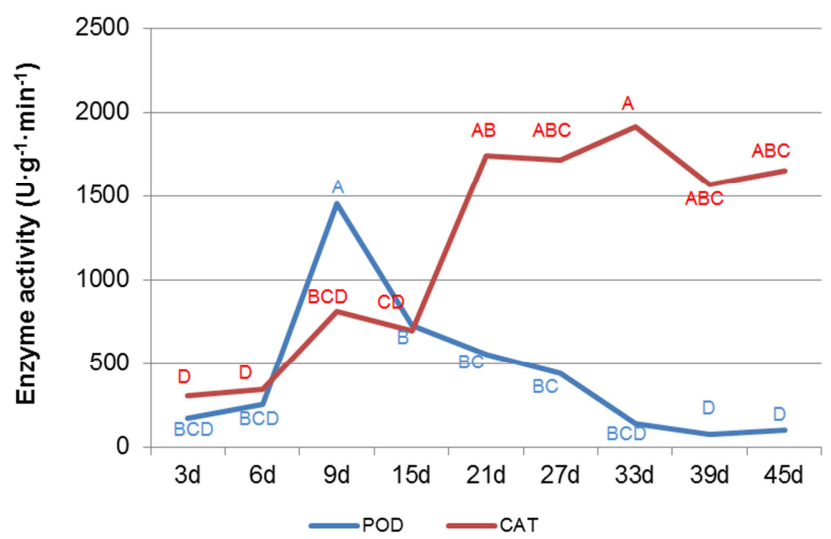

Figure 7. Activities of Peroxidase (POD) and Catalase (CAT) in seeds of castor bean measured at successive days during grain filling. For each enzyme, different letters indicate significant differences between the sampling days at $P \leq 0.05$.

The activity of POD changed significantly during grain filling, POD activity increased from day 3 to day 9 when it reached a peak and then decreased. On day 9, POD activity 
reached $1456 \mathrm{U} \cdot \mathrm{g}^{-1} \cdot \mathrm{min}^{-1}$ which is almost 20 times higher than the activity measured at the end of grain filling, on day 45. A significant change in the activity of CAT during grain filling was observed. CAT activity increased sharply between day 3 and day 15 and then remained high until the end of the experiment. Interestingly, the sharp increase in POD activity between day 6 and day 9 preceded the increase in CAT activity starting on day 15 . As already mentioned, PBZ application had no significant effect on the activity of those enzymes (Figure 7).

\section{Discussion}

The major goal of this study was to assess the effects of PBZ application on castor bean growth, yield, and physiology. PBZ is a synthetic plant growth retardant that inhibits gibberellin biosynthesis and has been used to control vegetative growth and to enhance flowering and fruiting patterns to obtain improved economic yields of several crops. PBZ is known to cause several physiological changes in plants including reduction of vegetative growth, flower induction, enhanced flowering, senescence retardation and increased seed yields [33]. However, as other plant growth regulator, its action depends on the rate and time of application as well as on the environmental conditions in the field [34].

\subsection{Yield and Physiology}

In the present field study, three PBZ concentrations were applied twice, once at grain filling of main panicle and once at grain filling of branched panicle. The growth and physiological responses of castor bean were measured four times throughout flowering and seed formation stages (E, A, M and B).

Plant height increased during flowering and seed formation and there was a tendency for PBZ to reduce plant height at anthesis (A) and maturity (M). However this typical growth retardant effect was not significant and could not be detected at late maturity (B). Mabvongwe, et al. [35] observed that to reduce potato stem length, PBZ has to be applied early during plant development. In this study, late application of PBZ at the onset of grain filling could have reduced its retardant effect. The lack of effects of PBZ on the number of branches of castor bean during the experiment could also be explained by its late application. With Camelina, PBZ application was effective in reducing plant height while increasing the number and thickness of branches [36].

On the other hand, an application rate of $75 \mathrm{~g} \cdot \mathrm{ha}^{-1}$ of PBZ induced a significant effect on leaf area which remained stable from anthesis until late maturity, while it decreased during the later stages of maturity for the two other treatments. A PBZinduced delay in leaf senescence was observed for field-grown Camelina sativa [36] and was reported to be linked with a PBZ- enhanced endogenous level of cytokinins. In this experiment, the fact that leaves of $75 \mathrm{~g} \cdot \mathrm{ha}^{-1} \mathrm{PBZ}$-treated plants remained on plant longer likely kept the plants photosynthetically active for a longer time which might have contributed to a cascade of events leading to better seed productivity. Carbon (C) that is fixed in photosynthesis is partitioned, between sucrose synthesis for immediate use and export, and starch synthesis to support maintenance respiration while the remaining $\mathrm{C}$ is available for growth. In castor bean, biomass partitioning to either stem, leaves, or panicle depends on the plant development stage. In this study, two critical periods for panicle formation could be identified based on dry weight accumulation: a first step between $\mathrm{E}$ and $\mathrm{A}$, and a second step between M and B. During the first step, the sink strength of panicle is clearly shown by a large accumulation of soluble sugars in this organ while it decreased in stems and leaves. Later on, the fact that leaves remained on the plant between $\mathrm{M}$ and $\mathrm{B}$ under $75 \mathrm{~g} \cdot \mathrm{ha}^{-1}$ PBZ could have further accelerated panicle formation through the availability of a larger pool of $\mathrm{C}$ during this critical period. The larger starch accumulation in leaves, stems and panicle observed in PBZtreated plants as compared to control plants could be another mechanism to increase the pool of carbohydrates available for panicle formation.

As a major consequence of PBZ application, the number of seeds per plant increased significantly as compared to control plants. This could be linked with the length of panicle which was also enhanced by PBZ application at late flowering. Other seed-related traits such as width of panicle, capsule number, seed length, seed width, and seed weight were not affected by PBZ application. Increased seed yield in response to PBZ application were reported in Brassica [37] and tomato [38]. However, over a certain range of concentration, PBZ could cause major seed losses as shown by Kumar, et al. [36] who tested five PBZ application rates on oil yield of Camelina sativa. In this experiment, it seems that PBZ was not applied at concentration causing detrimental effects. However, when applying growth regulators, environmental conditions have to be taken into account, in addition to time of application and dosage. Thus, further studies are needed to recommend optimal PBZ management for castor bean. Taken together, the results suggest that the effect of PBZ on seed yield improvement is likely due to larger $\mathrm{CO}_{2}$ assimilation due to a delay in leaf senescence and enhanced sink strength of panicles. Application of plant growth regulator at flower initiation can alter photosynthetic partitioning in favor to seed production.

\subsection{Antioxidant Enzymes in Seeds}

Grain filling is a critical period for oil yield of Castor bean. Once capsules are set, yield is proportional to seeds weight. Thus a better understanding of the environmental effects on seed size and yield is warranted [39].

The maximum temperature, total rain and the percentage of salinity were measured at the field site (Table 1). The relatively high salinity level [40] as well as the high maximum temperature [41] that were recorded during the growth period may have cause abiotic stresses in Castor bean. Interestingly, in addition to its role as growth retardant, PBZ has been reported to increase abiotic stress tolerance through an increase in antioxidant activity in treated plants [42-43]. An increase in 
the activity of antioxidative enzymes under salt and temperature stresses could be indicative of an increased production of ROS and a build-up of protective mechanisms to reduce oxidative damage triggered by abiotic stress [24]. POD and CAT are free radical scavenger in plants that can protect against stress by reducing free radical damages.

The activity of POD and CAT were measured as indicators of Castor bean response to abiotic stress during the critical period of grain filling. A large increase in POD activity early during grain filling stage followed by a rapid decrease between day 9 and day 15 was observed. On day 15, a sharp increase in CAT activity was observed. It is noticeable that between day 9 and day 15, Castor bean showed a rapid accumulation of biomass in grains (Figure 6) concomitantly with a decrease in POD activity and an increase in CAT activity, the two enzymes showing opposite change trends (Figure 7). This could indicate that POD and CAT does not work simultaneously but rather in a successive fashion during grain filling of Castor bean. Except on day 9, the activity of CAT was always higher than POD which could be explained by the rapid, turnover rates of CAT: one molecule of CAT can convert 6 million molecules of $\mathrm{H}_{2} \mathrm{O}_{2}$ to $\mathrm{H}_{2} \mathrm{O}$ and $\mathrm{O}_{2}$ per minute. As such, CAT plays a major role in the removal of $\mathrm{H}_{2} \mathrm{O}_{2}$ generated in peroxisomes by oxidases involved in boxidation of fatty acids, photorespiration and purine catabolism [44]. Contrary to the observation of Meloni et al. [24] with cotton under salt stress, a sustained increase in POD activity was not observed in castor bean. This may related to the fact that an obvious and continuously increasing external stress was not set in this experiment. In addition, PBZ showed no effect on CAT and POD activity in the seeds during grain filling. This could also be due to the level of stress that was not sustained throughout the experiment. However, this study did not take into account the isozyme profiles of the antioxidant enzymes and their potential relation to stress tolerance.

\section{Conclusions}

The application of PBZ did not affect the growth of castor bean, maybe due to an untimely application of this growth regulator. However, the number of seeds per plant increased with PBZ application which could be linked to a delayed leaf shedding and an increased accumulation of starch in panicles. The study suggests that it is possible to use PBZ at appropriate concentrations to enhance sink strength of panicles and improve seed yield of castor bean in coastal China.

\section{Acknowledgements}

This work was supported in part by the Jiangsu Provincial Key R \& D Program (BE2016345), Jiangsu Provincial Agricultural Innovation Fund (CX16(1005)), and the Priority Academic Program Development of Jiangsu Higher Education Institution. We wish to thank Dr. Annick Bertrand from Agriculture and Agri-Food Canada for the review of the manuscript and English editing. To the best of our knowledge, the named authors have no conflict of interest, financial or otherwise. Chengyu Song and Guanglong Zhu contributed equally to this paper and both considered as first authors.

\section{References}

[1] F. Labalette, A. Estragnat, and A. Messéan, "Development of castor bean production in France," 1996.

[2] H. Mutlu and M. A. Meier, "Castor oil as a renewable resource for the chemical industry," European Journal of Lipid Science and Technology, vol. 112, no. 1, pp. 10-30, 2010.

[3] A. Scarpa and A. Guerci, "Various uses of the castor oil plant (Ricinus communis L.) a review," Journal of ethnopharmacology, vol. 5, no. 2, pp. 117-137, 1982.

[4] M. N. Belgacem and A. Gandini, "Materials from vegetable oils: major sources, properties and applications," in Monomers, polymers and composites from renewable resources: Elsevier, 2008, pp. 39-66.

[5] M. Dwivedi and S. Sapre, "Total vegetable - oil based greases prepared from castor oil," Lubrication Science, vol. 19, no. 3, pp. 229-241, 2002.

[6] A. R. Olivares, R. Carrillo-González, M. d. C. A. GonzálezChávez, and R. M. S. Hernández, "Potential of castor bean (Ricinus communis L.) for phytoremediation of mine tailings and oil production," Journal of environmental management, vol. 114, pp. 316-323, 2013.

[7] N. D. L. Da Silva, M. R. W. Maciel, C. B. Batistella, and R. Maciel Filho, "Optimization of biodiesel production from castor oil," Applied biochemistry and biotechnology, vol. 130, no. 1-3, pp. 405-414, 2006.

[8] P. Berman, S. Nizri, and Z. Wiesman, "Castor oil biodiesel and its blends as alternative fuel," Biomass and Bioenergy, vol. 35, no. 7, pp. 2861-2866, 2011.

[9] M. N. Vara Prasad and H. M. de Oliveira Freitas, "Metal hyperaccumulation in plants: biodiversity prospecting for phytoremediation technology," Electronic journal of biotechnology, vol. 6, no. 3, pp. 285-321, 2003.

[10] H. Huang et al., "The phytoremediation potential of bioenergy crop Ricinus communis for DDTs and cadmium cocontaminated soil," Bioresource technology, vol. 102, no. 23, pp. 11034-11038, 2011.

[11] L. Cuiping, W. Chuangzhi, Yanyongjie, and H. Haitao, "Chemical elemental characteristics of biomass fuels in China," (in English), Biomass and Bioenergy, Article vol. 27, no. 2, pp. 119-130, 2004.

[12] I. J. O. Ogombe, "Effect of plant density and phosphate fertilizer on the growth, flower - and pod abscission, yield and yield components of pigeon peas (CAJANUS CAJAN (L.) MILLSP.)," M Sc, 1978.

[13] U. Chandrasekaran and A. Liu, "Endogenous abscisic acid signaling towards storage reserve filling in developing seed tissues of castor bean (Ricinus communis L.)," Plant Growth Regulation, vol. 72, no. 2, pp. 203-207, 2014.

[14] L. G. Nickell, Plant growth regulators. Agricultural uses. Springer-Verlag, 1982. 
[15] T. D. Davis, G. L. Steffens, and N. Sankhla, "Triazole plant growth regulators," Horticultural Reviews, Volume 10, pp. 63-105, 1988.

[16] A. Ghosh, J. Chikara, D. Chaudhary, A. R. Prakash, G. Boricha, and A. Zala, "Paclobutrazol arrests vegetative growth and unveils unexpressed yield potential of Jatropha curcas," Journal of Plant Growth Regulation, vol. 29, no. 3, pp. 307$315,2010$.

[17] S. Hua et al., "Paclobutrazol application effects on plant height, seed yield and carbohydrate metabolism in canola," International Journal of Agriculture and Biololy, Faisalabad, vol. 16, no. 1, pp. 471-479, 2014.

[18] T. Tekalign and P. Hammes, "Response of potato grown under non-inductive condition paclobutrazol: shoot growth, chlorophyll content, net photosynthesis, assimilate partitioning, tuber yield, quality, and dormancy," Plant Growth Regulation, vol. 43, no. 3, pp. 227-236, 2004.

[19] T. D. Davis, E. A. Curry, and G. L. Steffens, "Chemical regulation of vegetative growth," Critical reviews in plant sciences, vol. 10, no. 2, pp. 151-188, 1991.

[20] G. Paliyath and R. Fletcher, "Paclobutrazol treatment alters peroxidase and catalase activities in heat-stressed maize coleoptiles," Physiol. Mol. Biol. Plants, vol. 1, pp. 171-178, 1995.

[21] R. G. Pinhero, M. V. Rao, G. Paliyath, D. P. Murr, and R. A. Fletcher, "Changes in activities of antioxidant enzymes and their relationship to genetic and paclobutrazol-induced chilling tolerance of maize seedlings," Plant physiology, vol. 114, no. 2, pp. 695-704, 1997.

[22] S. S. Gill, N. A. Khan, N. A. Anjum, and N. Tuteja, "Amelioration of cadmium stress in crop plants by nutrients management: morphological, physiological and biochemical aspects," Plant Stress, vol. 5, no. 1, pp. 1-23, 2011.

[23] R. D. Allen, "Dissection of oxidative stress tolerance using transgenic plants," Plant physiology, vol. 107, no. 4, p. 1049, 1995 .

[24] D. A. Meloni, M. A. Oliva, C. A. Martinez, and J. Cambraia, "Photosynthesis and activity of superoxide dismutase, peroxidase and glutathione reductase in cotton under salt stress," Environmental and Experimental Botany, vol. 49, no. 1, pp. 69-76, 2003.

[25] Yangzhou environmental protection, "http://hbj.yangzhou.gov.cn/yzhbjceshi/ndhjzlgb/201706/7e30 1a0630a64c5e918d3159f3e14d08.shtml," 2016.

[26] Yangzhou environmental protection, "http://hbj.yangzhou.gov.cn/yzhbjceshi/zljb/201801/24/content 6732cbf6e7ed4fec92515b5647d24ca2.shtml," 2017.

[27] China weather website, "http://lishi.tianqi.com/yangzhou/201607.html," 2016-7-26, 2016.

[28] China weather website, "http://lishi.tianqi.com/yangzhou/201707.html " 2017-7-23, 2017.

[29] A. Laurentin, M. Cárdenas, J. Ruales, E. Pérez, and J. Tovar, "Preparation of indigestible pyrodextrins from different starch sources," Journal of Agricultural and Food Chemistry, vol. 51, no. 18 , pp. 5510-5515, 2003.
[30] Z. Wang and B. Luh, "Characterization of soluble and bound peroxidases in green asparagus," Journal of Food Science, vol. 48, no. 5, pp. 1412-1417, 1983.

[31] G. Cohen, D. Dembiec, and J. Marcus, "Measurement of catalase activity in tissue extracts," Analytical biochemistry, vol. 34, no. 1, pp. 30-38, 1970.

[32] A. S. S. software, "SAS/STAT software, Version 9.4 of the SAS System for Windows, Copyright (C) 2015, SAS Institute Inc., Cary, NC, USA," 2015.

[33] K. Kishore, H. Singh, and R. Kurian, "Paclobutrazol use in perennial fruit crops and its residual effects: A review," Ind. J. Agric. Sci, vol. 85, pp. 863-872, 2015.

[34] S. Hoffmann-Benning and H. Kende, "On the role of abscisic acid and gibberellin in the regulation of growth in rice," Plant Physiology, vol. 99, no. 3, pp. 1156-1161, 1992.

[35] O. Mabvongwe, B. T. Manenji, M. Gwazane, and M. Chandiposha, "The effect of paclobutrazol application time and variety on growth, yield, and quality of potato (Solanum tuberosum L.)," Advances in Agriculture, vol. 2016, 2016.

[36] S. Kumar, S. Ghatty, J. Satyanarayana, A. Guha, B. Chaitanya, and A. R. Reddy, "Paclobutrazol treatment as a potential strategy for higher seed and oil yield in field-grown Camelina sativa L. Crantz," BMC research notes, vol. 5, no. 1, p. 137, 2012.

[37] R. Setia, G. Bhathal, and N. Setia, "Influence of paclobutrazol on growth and yield of Brassica carinata $\mathrm{A}$. Br," Plant growth regulation, vol. 16, no. 2, pp. 121-127, 1995.

[38] M. Berova and Z. Zlatev, "Physiological response and yield of paclobutrazol treated tomato plants (Lycopersicon esculentum Mill.)," Plant Growth Regulation, vol. 30, no. 2, pp. 117-123, 2000.

[39] C. Wiegand and J. Cuellar, "Duration of Grain Filling and Kernel Weight of Wheat as Affected by Temparature 1," Crop Science, vol. 21, no. 1, pp. 95-101, 1981.

[40] Z. Y.-h. LIU Chen, Y. L. FU Qing-lin, and J. Xiao-ming, "Isolation and characterization of bacterium with ACC deaminase activity and its effect on salt tolerance of eggplant.," Journal of Zhejiang University (Agric. \& Life Sci.), vol. 34, no. (2), pp. 143-148, 2008.

[41] I. Havaux, "Rapid photosynthetic adaptation to heat stress triggered in potato leaves by moderately elevated temperatures," Plant, Cell \& Environment, vol. 16, no. 4, pp. 461-467, 1993.

[42] T. E. Kraus and R. A. Fletcher, "Paclobutrazol protects wheat seedlings from heat and paraquat injury. Is detoxification of active oxygen involved?," Plant and Cell Physiology, vol. 35, no. 1, pp. $45-52,1994$.

[43] S. Lurie, R. Ronen, Z. Lipsker, and B. Aloni, "Effects of paclobutrazol and chilling temperatures on lipids, antioxidants and ATPase activity of plasma membrane isolated from green bell pepper fruits," Physiologia Plantarum, vol. 91, no. 4, pp. 593-598, 1994.

[44] A. N. Polidoros and J. G. Scandalios, "Role of hydrogen peroxide and different classes of antioxidants in the regulation of catalase and glutathione $\mathrm{S}$ - transferase gene expression in maize (Zea mays L.)," Physiologia Plantarum, vol. 106, no. 1, pp. 112-120, 1999. 